\section{Contemporary Issues of Special Education in Turkey}

\author{
AUTHORS \\ Muhammed A. Karal \\ Journal of Special \\ Education Preparation \\ 1(2), 56-64 \\ (C) 2021 Karal \\ Licensed with CC-BY-NC-ND 4.0 \\ License \\ DOI: 10.33043/JOSEP.1.2.56-64 \\ openjournals.bsu.edu/JOSEP
}

\title{
ABSTRACT
}

The first international declaration of inclusive education through the Salamanca Statement (UNESCO, 1994) underlined the importance and necessity of inclusive practices and recommended that all students should benefit from the same educational approaches in the same environment. In addition to that, growth in field applications, published research papers, the number of trained professionals, and general awareness around students with disabilities triggered the improvement of special education services in Turkey during the last three decades. This article displays a brief history of special education, laws and regulations, the path of special education, and introduces contemporary issues in special education in Turkey. Without recognizing the existing situation and contemporary issues of the field of special education, it is not possible to take steps for planning and obtain better outcomes.

\section{KEYWORDS}

\section{Inclusion, special education, teacher training, Turkey}

$\mathbf{T}$ he number of individuals with disability are increasing and will continue to increase due to chronic health conditions. The population of people who live with some form of disability is more than a billion globally, which is around one in seven people and representing about $15 \%$ of the world's population (World Health Organization, 2015). According to the World Health Organization, around 90 million children or $1 / 20$ of children under 15 years of age experience moderate to severe disability and more than 100 million adults experience significant difficulties in functioning. While this is the case globally, national statistics are influenced by the country's conditions such as health services, environmental factors, violence, and natural disasters. In Turkey, the population of individuals with disability is stated as $12.29 \%$ by Turkish Statistical Institute (TSI, 2002). Although the up-to-date number of individuals with disability is not clearly known and the last legitimate statistic is almost 20 years old, for which data collected from smaller samples by different institutions were gathered, it can be concluded that the number of individuals with disabilities is more than $10 \%$ of the population which equates to around 8.5 million individuals.

In 1994, the United Nation's educational agency (UNESCO), supported by 92 governments and 25 international organizations met in Salamanca, Spain at the World Conference on Special Needs Education. As a result, the Salamanca Statement was adopted highlighting every child's right for education and identified the importance of educational placement in regular education systems for all children from various backgrounds. Moreover, article 25 of the UN Convention on the Rights of Persons with Disabilities (CRPD) emphasizes the right of reaching the highest standards for all individuals with disability without any discrimination. However, the reality is that many countries have difficulties providing quality services for individuals with disabilities (e.g., Hollenweger, 2014; Kohen et al., 2010; Kolupayeva et al., 2014). Dissemination of special 
education and support services around the world has been widely supported in the last few decades and these practices are elevating the discussion on addressing the needs of all individuals with disabilities as well as enacting laws and regulations to provide these services. Many of the legislative acts and foundational principles of special education (e.g., the least restrictive environment) in Turkey were modelled after policies in the United States. However, for specific practices and services in special education, it would be more practical to look from a regional perspective.

\section{History of Special Education in Turkey}

The Republic of Turkey was established in 1923, however the history of special education goes back hundreds of years to the Ottoman Empire. The first formal education started during 15 th century where gifted and talented children were systematically selected and educated in Enderun School (Melekoglu et al., 2009). The purpose of systematic selection and replacement in Enderun School was targeted at educating talented children who would become future scientists, artists and leaders (Enc et al., 1987). For the Republic of Turkey, the first formal special education school was The School for Deaf, Mute and Blind which was established in İzmir (Melekoglu, 2014). The school provided services for students with hearing impairments and visual impairments under the responsibility of Ministry of Health and Social Welfare until 1950. During this decade, 1950s, significant steps were taken for special education in Turkey. Starting in 1951, the control over special education services were carried out by the Ministry of National Education (Senel, 1998). The first special education teacher training program (Department of Special Education) was opened at

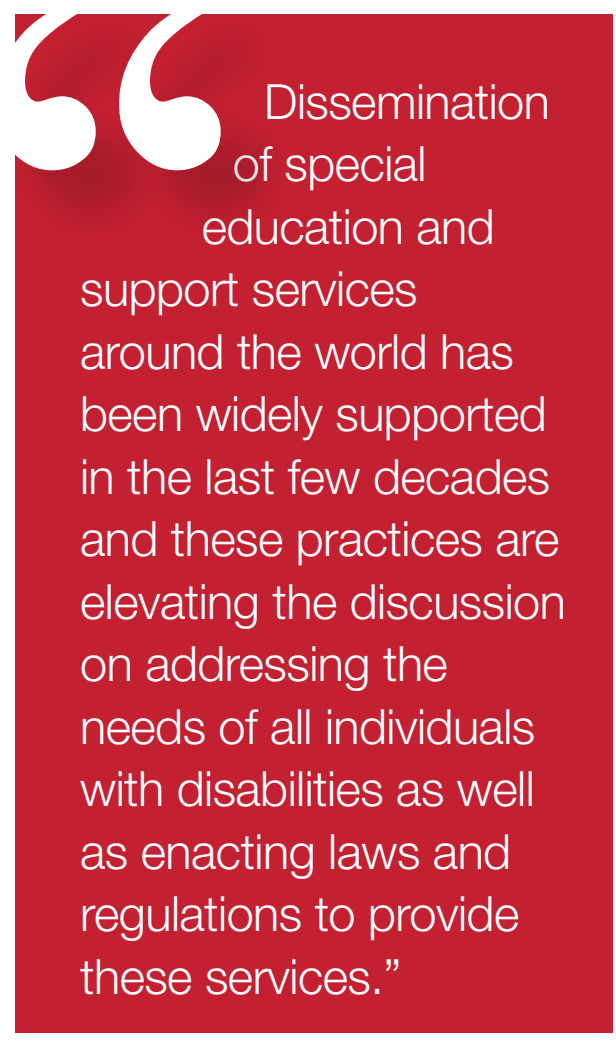

the Gazi Education Institute in Ankara in 1952, however the department was shut down after two years of training (Sahin, 2005). Moreover, the first Guidance and Research Center (GRC) was initiated in 1955. GRCs are institutions working under the Ministry of National Education, designed to develop and provide psychological and educational services for individuals with disabilities, families, and other stakeholders (Karasu, 2014). Main responsibilities of these centers related to special education services, including planning, providing, coordinating, monitoring, and evaluating the services (Ministry of National Education, 2020). GRCs are also the first destination of individuals after medical diagnosis and teacher/parent referral responsible for educational evaluation of children with disabilities. Furthermore, a limited number of special education classrooms were established in different primary schools in Ankara for students with intellectual disabilities for the first time in Turkey's history during 1955 (Sahin, 2005).

\section{Special Education Laws and Regulations}

A form of education that is special to individuals with disabilities was first mentioned in the Children in Need of Protection Law in 1949 (amendments in 1957, and 1958). Article 19 indicated that necessary institutions be established by the Ministry of National Education for children who require special education methods and these children undergo a period of observations before being accepted into these educational institutions. The two constitutional laws in force on education in Turkey (Ministry of National Education, 1961; Ministry of National Education, 1973) referred special education within a single article. These articles underlined that children with disabilities should be provided with special education and special precautions should be taken to raise children in need of special education and protection, respectively. The importance of special education in Turkey became even more prominent in 1980s when the Ministry of National Education established a division for special education services (Melekoglu, 2014). Following this decision, the first comprehensive regulation of Children with Special Education Needs Regulation became law in 1983. This law is the first by being specific to individuals with special needs and more significantly highlighting the importance of educational placement among typically developing peers. The purpose of this law was to regulate principles regarding the education of children with special education needs to secure a job and a profession, as well as, adapt to the environment and society. Disability categories, basic principles related to special education services, responsibilities of stakeholders such as public services and other professionals were defined (Senel, 1998). 
The growth in field applications, published research papers, the number of trained professionals, and general awareness around the subject triggered the improvement of special education services during 1990s. Decree Law No.573, enacted in 1997, is the first regulation that mentioned the term "Inclusion". This law is essential for special education in Turkey since it is considered as the first legal step of the country into inclusive education. The law includes the basic principles of special education underlining the importance of early intervention, educational evaluation, individualized education plans, parental involvement, as well as needs, interests, and abilities of all children with disabilities. In addition, with the adjustment provided by the Decree Law, special education expenses of children whose parents are insured and retirees affiliate to the Social Insurance Institution was covered by the government. Soon after the government become responsible for special education costs, the number of private special education and rehabilitation centers increased exponentially (Vuran \& Unlu, 2012). Based on the provisions of the Decree Law No.573, the Ministry of National Education legislated the Special Education Services Regulation (SESR) in 2000 (amendments in 2006, 2012, and 2018). The purpose of this law was to regulate principles to ensure that individuals with disabilities benefitted from special education services to receive academic and vocational education. Special education categories and some of the definitions included in this law are based on the Individuals with Disabilities Education Act (IDEA, 2004) and the Diagnostic and Statistical Manual of Mental Disorders (DSM; American Psychiatric Association, 2013).

\section{The Path of Special Education in Turkey}

The special education process begins when an individual is diagnosed with a disability in a hospital following a referral from a school administrator, a parent, or a request by the individual who has not previously been diagnosed with an intellectual disability and who is over the age of 18. After the medical diagnosis, the first encounter with a GRC occurs for the educational evaluation and identification process to place the individual in an appropriate educational program. GRCs make decisions regarding the individual's present levels of performance, and educational and supportive opportunities that are available in proximity. Then, following the educational evaluation, the GRCs' Special Education Evaluation Board prepares a report for the individual who is going to benefit from special education. These reports are prepared by considering the principle of the least restrictive environment. These GRC reports are usually issued on a 1-year basis, with rare exceptions of 6-month or 2-years. Following the evaluation process, the individual with disability might be directed to an inclusive general education classroom, a special education classroom in a general education school, a special education school, homeschooling, or hospital school (Ministry of National Education, 2018a). An individual with disability could also be directed to a private Special Education and Rehabilitation Centers (SERC) as another option, or an additional option to their educational placement based on the family's decision. For example, a student with a disability can receive education from both a special education classroom in a general education school while also receive face-to-face and/or group education in a SERC for part of the day. On the other hand, there are Science and Arts Centers for gifted children in addition to their regular education placements. The Turkish government covers the expenses of 8-hours face-to-face and 4-hours group education per month. If families decide to have more services and/or additional hours from SERCs, they are responsible for those extra costs. Regardless of the educational environment, it is mandated to prepare an IEP (MEB, 2018a) based on the individuals' needs and goals.

\section{Inclusion}

Inclusion, as a model of special education, refers to the education of students with disabilities in the same environment with typically developing peers (Kargin, 2004). Inclusion has become more prevalent in Turkey over the last decade. More than $70 \%$ of all students with disabilities in formal education spend at least $60 \%$ of their school time in the same classroom alongside their typically developing peers (Ministry of National Education, 2021). Table 1 indicates the total number of students in formal education in comparison with the total number of students with disabilities in formal education and the number of students who are placed in inclusive classrooms during the last decade.

Inclusion is more than physically placing all children from various backgrounds in the same classroom environment. The participations of students with disabilities must also include social and educational integration, and meaningful support services to achieve shared learning opportunities, new peer relationships, and raised expectations (Agran et al., 2014; Carter et al., 2015). Alongside an emphasis on the benefits of inclusive practices (Batu, 2008; Sucuoglu et al., 2020) and positive teacher attitudes (Rakap \& Kaczmarek, 2010; Sari, 2007), it is obvious that there are serious issues regarding the implementation of these practices (Vural \& Y1kmış, 2008; Yilmaz \& Batu, 2016). One of the most prominent barriers to inclusive practices is teachers' lack of knowledge and skills. It is found that the teachers' classroom management skills affect the behaviors 
TABLE 1: Number of Students and Teachers in Formal Education in Turkey

\begin{tabular}{|c|c|c|c|c|c|}
\hline \multirow[b]{2}{*}{ School Year } & \multicolumn{2}{|c|}{$\begin{array}{l}\text { TOTAL NUMBERS IN } \\
\text { FORMAL EDUCATION }\end{array}$} & \multicolumn{2}{|c|}{$\begin{array}{l}\text { TOTAL NUMBERS IN } \\
\text { SPECIAL EDUCATION }\end{array}$} & \multirow{2}{*}{$\begin{array}{c}\text { TOTAL NUMBER } \\
\text { IN INCLUSION } \\
\text { Students }\end{array}$} \\
\hline & Students & Teachers & Students & Teachers & \\
\hline $2019-2020$ & $18,241,881$ & $1,117,686$ & 425,774 & 15,321 & 318,300 \\
\hline 2018-2019 & $18,108,860$ & $1,077,307$ & 398,815 & 14,043 & 295,697 \\
\hline 2017-2018 & $17,885,248$ & $1,030,130$ & 353,610 & 12,846 & 257,770 \\
\hline 2016-2017 & $17,702,938$ & 989,231 & 333,598 & 12,009 & 242,486 \\
\hline $2015-2016$ & $17,588,958$ & 993,795 & 288,489 & 11,595 & 202,541 \\
\hline 2014-2015 & $17,559,989$ & 919,393 & 259,282 & 10,596 & 183,221 \\
\hline 2013-2014 & $17,532,988$ & 873,747 & 242,716 & 9,733 & 173,117 \\
\hline $2012-2013$ & $17,234,452$ & 832,726 & 220,649 & 10,344 & 161,295 \\
\hline 2011-2012 & $16,905,143$ & 774,602 & 199,513 & 8,139 & 148,753 \\
\hline $2010-2011$ & $16,845,528$ & 743,564 & 141,248 & 7,868 & 92,355 \\
\hline
\end{tabular}

of students with disabilities in inclusive classrooms (Sucuoğlu et al., 2010) and the academic communication of teachers with students with disabilities is deficient (Guner-Yildiz, 2015).

\section{Teacher Training}

After the shutdown of the first attempt to train special education teacher candidates in 1952, teacher training for special education was initiated in 1983 for the second time at the Anadolu University in Eskisehir. A candidate had to take a nationwide student selection and placement exam to qualify into the undergraduate program. Teacher candidates of a special education department are required to complete a 4-year special education teacher education program. Teacher candidates are supposed to complete 150 credits that are composed of general knowledge (13\%), teaching knowledge (28\%), and field knowledge (59\%) subcategories (Council of Higher Education, 2018). The teaching knowledge category includes a mandatory 10-credits of teaching practicum during the last two semesters of undergraduate education. Teacher candidates who graduate from a Special Education Department earn the title of special education teacher. However, not all title holders are graduates from Special Education Departments. Since special education is relatively new, and the number of students with disabilities surpasses the number of special education graduates, the Ministry of National Education started short-term certificate programs that were earmarked to produce more teachers into the system (Unlu et al., 2019). The short-term certificate programs have helped increase the number of teachers that are working in special education schools. As Cavkaytar (2018) noted, many of the teachers working in special education schools participated in the short-term certificate program. Though the program has helped in providing large numbers of teachers, it is a matter of debate how these short-term programs are going to close the gap and how these trainings produce qualified teachers. Research studies indicate that teachers who graduate from a special education department perform significantly better than teachers holding short-term certificates (Nougaret et al., 2005) and teachers with certificates need more help and support related to the education of students with disabilities (Sivrikaya \& Yikmis, 2016).

The identification process, educational placement, and teacher training are essential aspects of the path of special education worldwide. Especially when it comes to the education of individuals with disabilities and preparing qualified teachers, many countries experience various challenges and issues (e.g., Garcia-Cedillo et al., 2014; Kolupayeva et al., 2014). Turkey uses a unique assessment method for children with disabilities compared to those used in most countries which may create its own problematic issues.

\section{Contemporary Issues in Special Education}

There are many challenges in Turkey related to special education that are 
discussed by students, family members, researchers, and practitioners in the field. In the next section of this article, five contemporary issues of special education in Turkey are presented.

\section{Identification and Placement}

How and when to identify students with disabilities are primary questions of the process. It is not difficult to come up with responses such as "by collecting data" and "as early as possible." However, these answers will bring along more questions like "what type of standardized measures were employed to collect data?" or "what if the intervention they receive are not actually needed?" Furthermore, implementation methods for the identification in each state or county might change the process dramatically. In Turkey, educational evaluations and identifications of individuals with disabilities are done by GRCs. These centers work under the Ministry of National Education with responsibilities of designing and providing both educational and psychological services for individuals with disabilities, their parents, and their teachers (Karasu, 2014).

Turkey's SESR (2018) highlighted that GRCs are responsible for the identifications, educational placements, and supportive services for students with disabilities. Thus, GRC personnel make all decisions for the individual with disability regarding the type and degree of the disability, developmental characteristics, current performance, and educational placement. In a study conducted by Karasu (2014), parents expressed concern about the evaluation process done with their children and had mostly negative experiences with GRC personnel in terms of inadequacy, professionalism, guidance, and bureaucracy. In another research study about GRCs, parents of individuals with intellectual disabilities described their unsatisfactory experiences related to their children's educational evaluation, personnel communication, and overall GRC collaboration (Karal \& Unluol-Unal, under review). In a study conducted with GRC administrators, participants stated problems related to the identification process as allocating insufficient time for an individual to be evaluated and lacking a sufficient number of experts in GRCs (Ozak et al., 2008). In fact, GRC personnel have indicated that that their greatest area of need for in-service training is on conducting standardized evaluations (Aslan \& Bal, 2014).

\section{Support Services}

Meeting the needs of all students with disabilities is only possible when they have access to support services. Support services are essential for not only meeting the needs of students with disabilities, but also enhancing the quality of special education services for all stakeholders that include, teachers, professionals, family members, and the students with disabilities themselves. These services consist of in-class and out-of-class educational support, assistive technology, social supports, guidance and counseling, and related services such as health services, physical therapy, occupational therapy, and speech-language therapy. The first issue related to the support services is about the understanding of the concept of "support," since it is usually mentioned to refer supporting education of students with disabilities (i.e., supportive education services and resource room). However, there are serious challenges for families to reach support services such as social support, legal rights, guidance and psychological counseling, and parent training opportunities due to their needs and expectations (SardohanYildirim \& Akcamete, 2014). Mothers of students with disabilities indicate that support services are not sufficient either for their children or family members
(Baglama \& Sakalli- Demirok, 2016).

Second, as the number of inclusive classrooms increase, and the necessity is highlighted in the law, there remains little support services in schools (Melekoglu, 2014). Results of the project on Investigating the Efficacy of Supportive Special Education Services showed that necessary support services are not provided to the students with disabilities or their teachers. Teachers stated that they have difficulties and need support services related to education of students with disabilities, problem behaviors, and informing typically developing peers (Yenigun \& Odluyurt, 2020). It is mandatory to have a resource room and provide educational support services in each school where students with disabilities are placed (Ministry of National Education, 2015). The purpose of a resource room is to create an opportunity for teachers to work with students in small groups or face-to-face to provide individualized education (Moody et al., 2000). However, resource rooms are not appropriately designed, lack specific planning and curriculum, and the environment is not appropriate for students with special needs (Pemik \& Levent, 2019; Yazicioglu, 2020).

\section{Gap between the Research and Practice}

Another issue of special education in Turkey is related to the implementation of evidence-based practices and research-based practices such as classroom management strategies to meet the needs of students with disabilities. The purpose of these practices is to promote positive outcomes for students from various backgrounds. These practices should be utilized to design individualized education and interventions since the effectiveness is established. Although there are many practices and classroom management strategies that have been identified as scientifically rigorous by 
research, practitioners do not usually employ these practices (Lauderdale-Littin \& Brennan, 2018; Melekoglu, 2014). Thus, there is still a gap between research and practice, especially in inclusive classrooms.

Research indicates that effective classroom management decreases the likelihood of problem behaviors (Korpershoek et al., 2016) and increases student engagement by enhancing opportunities to respond and receive performance feedback (Simonsen et al., 2008). In a study conducted by Guner-Yildiz (2015), a high number of students with intellectual disabilities were found to be academically engaged (58.6\%) however, their teachers' approval for appropriate behaviors was low $(0.13 \%)$. The use of feedback increased students' academic engagement and on-task behaviors, while decreasing off-task and problem behaviors (Akalın \& Sucuoğlu, 2015). In a study conducted by Guner-Yildiz and Sazak- Pinar (2012) to examine teachers' behavior in inclusive classrooms, results indicated that none of the teachers used reinforcements for students with disabilities who followed the classroom rules and only $20 \%$ of teachers used reinforcements for students with disabilities who performed socially or academically appropriate behavior.

Potential reasons of not utilizing scientifically validated practices and strategies in the classroom include teachers' lack of training as well as lack of knowledge related to the deficits associated with a disability, which practices and strategies have been identified as evidence-based, and the prospective benefits of these practices (Lauderdale-Littin \& Brennan, 2018). A majority of general education teachers who teach in an inclusive environment are not equipped with support services and may have little awareness about evidence-based practices and effective classroom management strategies for student with disabilities (Melekoglu,

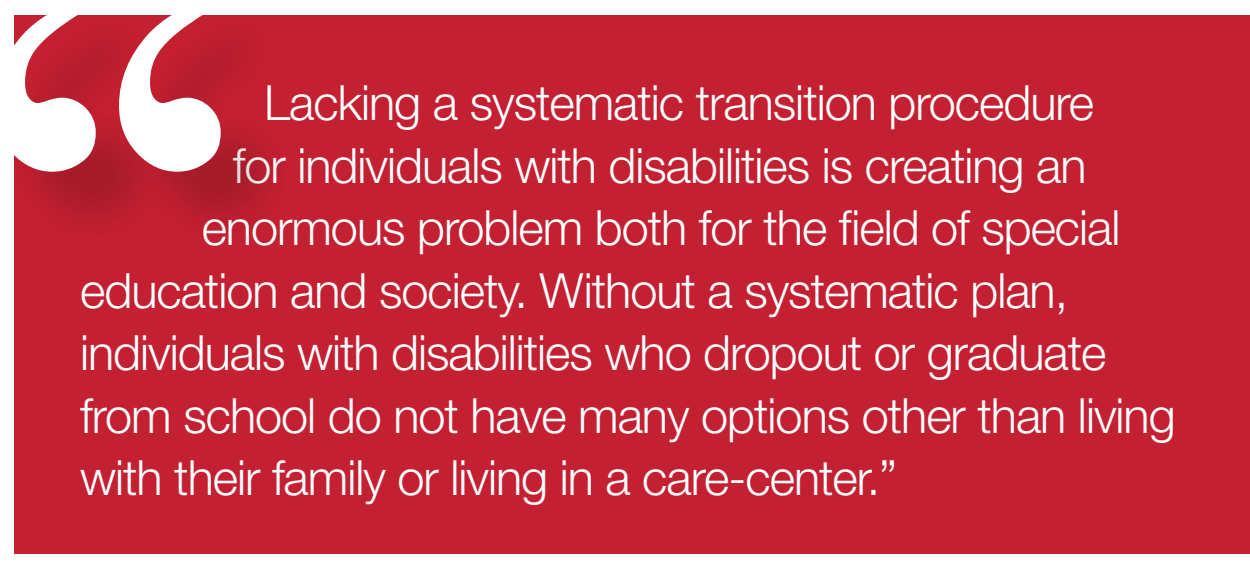

2014). Even if they know about these practices and strategies, they sometimes view them as not suitable with their classroom management techniques (Lang et al., 2010). In a study conducted by Ceylan and Yikmis (2017), teachers were asked about the type of intervention strategy they use when problem behaviors occurred and teachers stated that they used verbal warnings (44\%), tried to find the reason $(28 \%)$ and did nothing specific (12\%).

\section{Transition}

Transition involves changes and adjustments that occur cumulatively in the lives of individuals as they move through various experiences (Wehman, 2006). For instance, school-to-work transition might be defined as the status change that an individual makes from leaving the student role to an adult role and live in society (Defur et al., 2001). This transition process can be exciting and full of expectations and dreams for typically developing individuals while it may also be discouraging for individuals with disabilities and their families. Moreover, other additional factors such as economic situation, lack of opportunities, and societal attitudes may affect the possibilities of individuals with disabilities and their families in the transition process.

According to the SESR, one of the purposes of special education services is to prepare individuals with disabilities for employment, higher education, and social life. However, there is no transition procedure for individuals with disabilities in Turkey. Related to the after-school life of individuals with disabilities, some regulations appear to support their employment in order to prepare them for their adult lives. It is stated that a company employing fifty or more employees is obligated to employ $4 \%$ of individuals in governmental institutions and $3 \%$ of individuals with disabilities in private institutions. Lacking a systematic transition procedure for individuals with disabilities is creating an enormous problem both for the field of special education and society. Without a systematic plan, individuals with disabilities who dropout or graduate from school do not have many options other than living with their family or living in a care-center.

\section{Teacher Training}

Teacher training is another challenge for the field of special education in Turkey. This issue includes the training of special education teachers and general education teachers who are going to work in inclusive classrooms. Teacher training plays a vital role in promoting teacher candidates' willingness for inclusive practices and utilizing various strategies that can meet the individual needs of students with disabilities (Flo- 
rian \& Spratt, 2013). However, there is only one mandatory course called Special Education and Inclusion in the new program published in 2018 for general education teacher candidates to attend during their last year of undergraduate school. Furthermore, the structure of the program for general education teacher candidates does not involve any type of practicum opportunity with student with special needs. Research indicates that teachers lack knowledge and skills about inclusion and inclusive practices (Yilmaz \& Batu, 2016), and it is suggested that undergraduate programs should offer elective courses related to special education and teacher candidates should do school visits to gain more knowledge and develop positive attitudes towards students with disabilities (Akyildiz, 2017). Teachers' negative perspectives related to inclusive practices might interrupt their future educational applications (Forlin et al., 2009) and it is unlikely that those teachers will change their existing perspectives (Sharma et al., 2013).

The training that teacher candidates experience during their undergraduate education is considered to be one of the key factors in determining teacher candidates' perceptions regarding students from various backgrounds in their prospective schools and how they influence outcomes of students in inclusive environments (Mastropieri \& Scruggs, 2017). Improving the quality of programs for teacher candidates by adding more courses and professional development opportunities related to the special education and inclusive practices are essential for prospective teachers to meet the needs of all students from various backgrounds. However, enhancing the quality of undergraduate programs is not just about changing or designing the program but also about training more highly qualified faculty members. According to the Council of
Higher Education in Turkey, employing three faculty members is sufficient for programs to be opened for student registrations. Therefore, many special education departments are started with three faculty members for the purpose of filling the teacher shortage. Since there are not enough graduates with doctoral degrees in the field of special education, departments sometimes cannot even find three qualified faculty. Thus, teacher training in Turkey is experiencing significant and complicated issue for the future of special education.

\section{Conclusion}

The identification process, educational placement, and teacher training are essential components of special education worldwide. Even though the legal and practical steps of special education in Turkey are relatively new, the field has come a long way during the last three decades and is still improving. As with many other countries, there are issues and concerns related to special education that must be addressed to reach equal opportunity for all students. The contemporary issues of special education in Turkey addressed in this article could be summarized as a research and policy to practice gap. In order to reach better outcomes and overcome challenges in special education, it is essential to enhance the quality of teacher training programs and professional development opportunities for special educators in Turkey.

\section{References}

Agran, M., Brown, F., Hughes, C., Quirk, C., \& Ryndak, D. (Eds.). (2014). Equity and full participation for individuals with severe disabilities: A vision for the future. Brookes.

Akalin, S., \& Sucuoglu, B. (2015). Effects of classroom management intervention based on teacher training and performance feedback on outcomes of teacher-student dyads in inclusive classrooms. Educational Sciences: Theory \& Practice, 15(3), 739-758. https://doi.org/10.12738/estp.2015.3.2543
Akyildiz, S. (2017). Öğretmen adaylarinin engelli bireylere yönelik tutumlarinin incelenmesi [Examination of the teacher candidates' attitudes towards people with disabilities]. Sosyal Politika Calısmalarl Dergisi, 39, 141-175. https://doi. org $/ 10.21560 /$ spcd.vi.338158

American Psychiatric Association. (2013). Diagnostic and statistical manual of mental disorders (5th ed.). Washington, DC: Author.

Aslan, S., \& Bal, E. (2014). Rehberlik ve Araştırma Merkezleri'nin örgütsel analizi. [The organizational analysis of Guidance and Research Centers]. Eğitim ve Bilim, 39, 313-324. http://dx.doi.org/10.15390/ EB.2014.1652

Baglama, B., \& Sakalli-Demirok, M. (2016). Opinions of mothers of children with autism spectrum disorder towards special education support and services. International Journal of Educational Sciences, 15, 279- 289. https://doi.org/10.1080/09751122 .2016 .11890537

Batu, S. (2008). Kaynaştırma ve destek özel eğitim hizmetleri. [Inclusion and special education support services] İ. H. Diken (Ed.), Özel Eğitim [Special Education] (pp.89107). Ankara: Pegem Yayıncılık

Carter, E. W., Moss, C. K., Asmus, J., Fesperman, E., Cooney, M., Brock, M. E., Lyons, G., Huber, H. B., \& Vincent, L. B. (2015). Promoting inclusion, social connections, and learning through peer support arrangements. Teaching Exceptional Children, 48(1), 9-18. https://doi. org/10.1177\%2F0040059915594784

Cavkaytar, A. (2018). Özel eğitime gereksinim duyan çocuklar ve özel eğitim. [Children with special needs and special education] İ. H. Diken (Ed.), Özel eğitime gereksinimi olan öğrenciler ve özel eğitim (pp. 3-29). Pegem Akademi.

Ceylan, F., \& and Yikmis, A. (2017). Kaynaştırma öğrencilerinin sergilediği proglem davranışlara yönelik sınıf öğretmenlerinin uyguladıkları önleme ve müdahale stratejileri [The prevention and intervention strategies carried out by primary school teachers for problem behaviors on inclusive students]. Uludağ Üniversitesi Ë̆itim Fakültesi Dergisi, 31(1), 239-264. https:// doi.org/10.19171/uefad.323417

Council of Higher Education. (2018). Özel eğitim öğretmenliği lisans programı. [Special education teacher training undergraduate program].

Defur, S. H., Todd-Allen, M., \& Getzel, E. E. (2001). Parent participation in the transition planning process. Career Development and Transition for Exceptional Individuals 24(1), 19-36. https://doi.org/10.1177\% 2F088572880102400103

Enç, M., Çağlar, D., Özsoy, Y. (1987). Özel Eğitime Giriș. [Introduction to Special Education]. Üniversitesi Yayınları.

Florian, L., \& Spratt, J. (2013) Enacting 
inclusion: a framework for interrogating inclusive practice. European Journal of Special Needs Education, 28(2), pp.119135. https://doi.org/10.1080/08856257.201 3.778111

Forlin, C., Loreman, T., Sharma, U., \& Earle, C. (2009) Demographic differences in changing pre-service teachers' attitudes, sentiments and concerns about inclusive education. International Journal of Inclusive Education, 13(2), pp.195-209. https://doi. org/10.1080/13603110701365356

Garcia- Cedillo, I., Romero- Contreras, S., \& Fletcher, T. V. (2014). Special education today in Mexico. A. F. Rotatori, J. P. Bakken, S. Burkhardt, F. E. Obiakor, \& U. Sharma (Eds.). Special education international perspectives: Practices across the globe (pp. 61-89). Emerald Group Publishing.

Güner-Yıldız (2015). Teacher and student behaviors in inclusive classrooms. Educational Sciences: Theory and Practice, 15(1), 177-184.

Guner-Yildiz, N., \& Sazak-Pinar, E. (2012). Examining teachers' behavior related to students with special needs in inclusive classrooms. International Online Journal of Educational Sciences, 4(2), 475-488.

Hollenweger, J. (2014). Special education today in Switzerland. A. F. Rotatori, J. P. Bakken, S. Burkhardt, F. E. Obiakor, \& U. Sharma (Eds.). Special education international perspectives: Practices across the globe (pp. 243-269). Emerald Group Publishing.

Individuals with Disabilities Education Improvement Act of 2004, U.S.C. $\S 612$ et seq.

Karal, M. A., \& Unluol-Unal, N. (under review). The showcase of special education in Turkey: Guidance and research centers.

Karasu, N. (2014). Guidance and research centers of Turkey: from the perspectives of parents, European Journal of Special Needs Education, 29(3), 358-369. https://doi.org/1 $\underline{0.1080 / 08856257.2014 .909176}$

Kargın, T. (2004). Kaynaştırma: Tanımı, gelişı̇imi ve ilkeleri. [Inclusion: Definition, development and principles]. Ankara Üniversitesi Ĕgitim Bilimleri Fakültesi Özel Ĕ̈itim Dergisi, 5 (2), 1-13.

Kohen, D., Uppal, S., Kahn, S., \& Visentin, L. (2010). Access and barriers to educational services for Canadian children with disabilities. Canadian Council on Learning.

Kolupayeva, A., Taranchenko, O., \& Danilavichute, E. (2014). Special education today in Ukraine. A. F. Rotatori, J. P. Bakken, S. Burkhardt, F. E. Obiakor, \& U. Sharma (Eds.). Special education international perspectives: Practices across the globe (pp. 311-351). Emerald Group Publishing.

Korpershoek, H., Harms, T., de Boer, H., van Kuijk, M., \& Doolaard, S. (2016). A meta-analysis of the effects of classroom management strategies and classroom management programs on students' academic, behavioral, emotional, and moti- vational outcomes. Review of Educational Research, 86(3), 643-680. https://doi. org/10.3102\%2F0034654315626799

Lang, R., O’Reilly, M. F., Sigafoos, J., Machalicek, W., Rispoli, M., Shogren, K., Chan, J. M., Davis, T., Lancioni, G., \& .Hopkins, S. (2010). Review of teacher involvement in the applied intervention research for children with autism spectrum disorders. Education and Training in Autism and Developmental Disabilities, 45(2), 268-283. https://www.jstor.org/stable/23879811

Lauderdale-Littin, S., \& Brennan, M. (2018). Evidence-based practices in the public school: The role of preservice teacher training. International Electronic Journal of Elementary Education, 10(3), 369-375.

Mastropieri, M. A., \& Scruggs, T. E. (2017). The Inclusive Classroom: Strategies for Effective Differentiated Instruction. (6th edition). Pearson.

Melekoglu, M. A., Cakiroglu, O., \& Malmgren, K. W. (2009). Special education in Turkey. International Journal of Inclusive Education, 13(3), 287-298. https://doi. org/10.1080/13603110701747769

Melekoğlu, M. A. (2014). Special education today in Turkey. A. F. Rotatori, J. P. Bakken, S. Burkhardt, F. E. Obiakor, \& U. Sharma (Eds.). Special education international perspectives: Practices across the globe (pp. 529-557). Emerald Group Publishing.

Ministry of National Education (1957). Korunmaya Muhtaç Çocuklar Hakkında Kanun [Children in Need of Protection Law]. https://www.resmigazete.gov.tr/arsiv/9615. pdf

Ministry of National Education (1961). Ilkögretim ve Eğitim Kanunu [Elementary Education and Education Law]. https://www. resmigazete.gov.tr/arsiv/10705.pdf

Ministry of National Education (1973). Milli Ĕgitim Temel Kanunu [National Education Law]. https://www.resmigazete.gov.tr/ arsiv/14574.pdf

Ministry of National Education (1983). Özel Eğitime Muhtaç Çocuklar Kanunu [Children with Special Education Needs Regulation]. https://www.resmigazete.gov. tr/arsiv/18192.pdf

Ministry of National Education (1997). 573 Sayılı Özel Eğitim Hakkında Kanun Hükmünde Kararname [Decree Law No.573 on Special Education]. https://orgm.meb.gov. tr/meb iys dosyalar/2012 10/10111011 ozel_egitim_kanun hukmunda_kararname. pdf

Ministry of National Education (2015). Destek eğitim odası açılması genelge [Public mandate about resource rooms]. https://akram.meb.k12.tr/ meb iys dosyalar/42/03/814357/dosyalar/2016_02/24015220_201515genelge. pdf

Ministry of National Education (2018a). Özel Ĕ̈itim Hizmetleri Yönetmeliği. [Spe- cial Education Services Regulation]. http://orgm.meb.gov.tr/meb iys dosyalar/2018 07/09101900 ozel egitim hizmetleri yonetmeligi 07072018.pdf

Ministry of National Education (2018b). Rehberlik ve Araştırma Merkezi Kılavuzu. [Guidance and Research Center Guideline]. https://orgm.meb.gov.tr/meb iys dosyalar/2018 01/17234231_ram kilavuzu 2018.pdf

Ministry of National Education (2020). Rehberlik ve Araştırma Merkezleri Yönergesi. [Guidance and Research Center Instruction]. https://orgm.meb.gov.tr/meb iys dosyalar/2020_08/31230315_RAM_YONERGESY.pdf

Ministry of National Education (2021). Milli Ĕgitim İstatistikleri Örgün Ë̆itim 2019- 2020. [National Education Statistics Formal Education 2019- 20207. https://sgb.meb.gov.tr/meb iys dosyalar/2020 09/04144812 meb istatistikleri orgun egitim $20192020 . \mathrm{pdf}$

Moody, S. W., Vaughn, S., Hughes, M. T., \& Fischer, M. (2000). Reading instruction in the resource room: Set up for failure. $E x$ ceptional Children, 66, 305-316. https://doi. org/10.1177\%2F001440290006600302

Nougaret, A. A., Scruggs, T. E., \& Mastropieri, M. A. (2005). Does teacher education produce better special education teachers? Exceptional Children, 71(3), 217-229. https:// doi.org/10.1177\%2F001440290507100301

Ozak, H., Vural, M., \& Avcıoğlu, H. (2008). Rehberlik araştırma merkezi müdürlerinin gönderme, tanılama, yerleştirme, izleme ve değerlendirmeye ilişkin görüş ve önerileri [Guidance and Research Centers' administrators' opinions and suggestions through the procedure of referral, identification, placement, monitoring and evaluation].", Abant İzzet Baysal Üniversitesi Eğitim Fakültesi Dergisi, 7(1), 189-206.

Pemik, K., \& Levent, F. (2019). Üstün yetenekli ögrencilere destek odasında verilen eğitime ilişkin okul yöneticilerinin ve öğretmenlerin görüşleri [Views of school administrators and teachers on the education provided in the resource room for gifted students]. Ankara Üniversitesi Eğitim Bilimleri Fakültesi Özel Ĕ̈itim Dergisi, 20(2), 1-26. https:// doi.org/10.21565/ozelegitimdergisi.446598

Rakap, S. \& Kaczmarek., L. (2010). Teachers' attitudes towards inclusion in Turkey. European Journal of Special Needs Education, 25(1), 59-75. https://doi. org $/ 10.1080 / 08856250903450848$

Sahin, S. (2005). Özel eğitimin tarihçesi. [History of special education]. In A. Ataman (Ed.), Özel gereksinimli çocuklar ve özel eğitime giriş, (pp. 49-70). [Children with special needs and introduction to special education.] Gündüz Eğitim ve Yayıncılık.

Sardohan- Yildirim E., \& Akcamete G. (2014). Determination of difficulties encountered by mothers having children with multiple 


\section{ABOUT THE AUTHOR}

\section{Muhammed A. Karal}

Dr. Muhammed A. Karal earned his undergraduate degree in Special Education from Gazi University, Turkey. Dr. Karal earned his M.S. and Ph.D. in Special Education at The Pennsylvania State University. He is currently an assistant professor at Sinop University, Turkey. His research interests include effective instructional methods for teaching individuals with developmental disabilities, social interaction, community-based instruction, and school-to-work transition for all students with disabilities. disabilities during early childhood special education services process. Cumhuriyet International Journal of Education, 3(1), 74-89.

Sari, H. (2007). The influence of an in-service teacher training (inset) programme on attitudes towards inclusion by regular classroom teachers who teach deaf students in primary schools in Turkey. Deafness \& Education International, 9, 131-146. https:// doi.org/10.1179/146431507790559996

Senel, H. G. (1998). Special education in Turkey. European Journal of Special Needs Education, 13(3), 254-261. https://doi. org/10.1080/0885625980130304

Sharma, U., Forlin, C., Deppeler, J., \& Yang, G. (2013) Reforming teacher education for inclusion in developing countries in the Asia-Pacific region. Asian Journal of Inclusive Education, 1(1), 3-16.

Simonsen, B., Fairbanks, S., Briesch, A., Myers, D., \& Sugai, G. (2008). Evidence-based practices in classroom management: Considerations for research to practice. Education and Treatment of Children, 31(3), 351-380. https://www.jstor.org/ stable/42899983

Sivrikaya, T., \& Yıkmış, A. (2016). Özel eğitim sınıflarında görev yapan özel eğitim mezunu olan ve olmayan öğretmenlerin öğretim süreciyle ilgili gereksinimleri. [The instructional process requirements of special education graduate and non-graduate teachers working in special education classes] Abant İzzet Baysal Üniversitesi Ĕ̈itim Fakültesi Dergisi, 16(4). 1984-2001.

Sucuoğlu, B., Akalın, S., \& Sazak-Pınar, E. (2010). The effects of classroom management on the behaviors of students with disabilities in inclusive classrooms in Turkey. The Journal of the International Association of Special Education, 11(1), 64-74.

Sucuoğlu, B., Bakkaloğlu, H., \& Demir, E. (2020). The effects of inclusive preschools on the development of children with disabilities: A longitudinal study. International Journal of Early Childhood Special Education, 12(1), 215-231. https://doi. org/10.9756/INT-JECSE/V12I1.201006

Turkish Statistical Institute. (2012). Turkey disability survey. https://kutuphane.tuik.gov.tr/ pdf/0014899.pdf

UNESCO (1994). The Salamanca statement and framework for action on special needs education. Adopted by the World Conference on Special Needs Education: Access and Quality. UNESCO.

Unlu, O., Melekoglu, M. A., Unlu, E. (2019). Alan dışı özel eğitim öğretmenlerinin yeterliliklerine ilişkin çalışmaların incelenmesi [Review of researches related to competencies of special education teachers graduated from alternative certification programs]. Elementary Education Online, 18(4), 1609-1640. https://10.17051/ilkonline.2019.632528

Vural, M., \& Yıkmış A. (2008). Kaynaştırma sınıfı öğretmenlerinin öğretimin uyarlanmasına ilișkin yaptıkları çalıșmaların belirlenmesi [Determining the views of the teachers about the adaptations used in inclusive classrooms]. Abant Izzet Baysal Üniversitesi Eğitim Fakültesi Dergisi, 8(2), 141-159. https://dergipark.org.tr/en/pub/ aibuefd/issue/1495/18090

Vuran, S., \& Unlu, E. (2012). Türkiye'de özel gereksinimli çocukların eğitimi ile ilgili örgütlenme ve mevzuat. [Organization and legislation about education of students with special needs in Turkey]. In S. Vuran (Ed.), Özel eğitim [Special education.] (pp. 5780). Maya Akademi.

Wehman, P. (2006). Life beyond the classroom: Transition strategies for young people with disabilities (4th ed.). Paul H Brookes Publishing.

World Health Organization. (2015). World health statistics 2015. World Health Organization.

Yazıcıoğlu, T., (2020). Destek eğitim odalarında görev yapan öğretmenlerin gözüyle destek eğitim odaları [Resource rooms through the eyes of teachers working in resource rooms]. Ankara Üniversitesi Eğitim Bilimleri Fakültesi Özel Ĕ̈itim Dergisi, 21(2), 273-297. https://doi.org/10.21565/ozelegitimdergisi.584392

Yenigun, E., \& Odluyurt, S. (2020). Özel eğitim ve rehabilitasyon merkezlerinde kaynaştırma öğrencilerine sunulan destek hizmetler hakkında uygulamacı görüşleri [Practitioners' perspective about support services offered to inclusive students at special education and rehabilitation centers] Journal of Qualitative Research in Education, 8(3), 895- 919. https://dergipark.org.tr/en/pub/ enad/issue/56216/775121

Yılmaz, E., \& Batu, E. S. (2016). Farklı branştan ilkokul öğretmenlerinin bireyselleștirilmiş eğitim programı, yasal düzenlemeler ve kaynaştırma uygulamaları hakkındaki görüşleri [Opinions of primary school teachers about individualized education programme, legal regulation and inclusion implementation]. Ankara Üniversitesi Ĕgitim Bilimleri Fakültesi Özel Eğitim Dergisi, 17(3), 247-268. https://10.21565/ozelegitimdergisi.266140 